\title{
The work of Global Digital Heritage for the massive digitization of fortifications in Spain
}

\author{
Víctor Manuel López-Menchero Bendicho a , Herbert D. G. Maschner ${ }^{\text {b }}$, James Bart \\ McLeod $^{c}$, Jeffrey P. du Vernay ${ }^{d}$, Miguel Ángel Hervás Herrera ${ }^{\mathrm{e}}$
}

a,b,c,d,e Global Digital Heritage Inc., Gulfport, United States of America, gdh@ globaldigitalheritage.org

\begin{abstract}
In the last 20 years the field of cultural heritage has experienced a revolution in terms of documentation methods. The latest technological advances in laser scanners and photogrammetry have opened the possibility of documenting in three dimensions all types of monuments and sites regardless of their size or complexity. In this revolution fortified spaces have not been an exception. Hundreds of research teams around the world have developed 3D digitization projects of castles and fortresses. However, the overall impact of these projects has been very limited, partly due to the lack of collaboration and partly due to the inability of citizens to freely access the data.

Currently, the research team of the US non-profit entity Global Digital Heritage is working on the massive digitization of fortifications in Spain, regardless of their chronology or size. In this context, work has been done on digitizing the prehistoric fortified site of Motilla del Azuer in Daimiel, the Iberian oppidum of Cerro de las Cabezas in Valdepeñas, the fortified Islamic city of Calatrava La Vieja in Carrión de Calatrava, the medieval Christian castle of Calatrava La Nueva in Aldea del Rey, the medieval-Renaissance castle of Los Vélez in Mula, the watchtower of Cope in Águilas or the machine-gun bunker of the Spanish Civil War in Alhama de Murcia, to name just a few examples.
\end{abstract}

Keywords: 3D, photogrammetry, laser scanner, digital documentation.

\section{Introduction}

From the birth of virtual archeology at the end of the twentieth century to its expansion and widespread acceptance by the academic field now in the second decade of the twenty-first century, there have been many technological and theoretical transitions in the discipline. In the beginning, virtual reconstruction projects predominated (Forte, 1997). But in the last decade, with the development of faster digitization techniques, there have been thousands of projects related to the three-dimensional digitalization of various cultural heritage elements (González-Aguilera, et al., 2019), among them fortifications, castles, towers, walls and in general all types of defen- sive spaces (El-Hakim, et al., 2007; Angulo, 2013; Ruiz, et al., 2015; Bercigli, 2017; Muscatelloa, et al., 2018).

The focus of these works has been varied. Some have sought to develop new working methodologies in the field of new technologies applied to cultural heritage (Rodríguez-Navarro, et al., 2015; Almagro, Orihuela, 2015; Milella, et al., 2016; Rodríguez-Navarro, et al., 2016). Others have served to solve problems of historical and archaeological research on fortifications (Marotta, et al., 2017; Verdiani, Salvatori, 2017; Lo Faro, et al., 2016; Pignatale, et al., 2016; Man- 
cuso, Pasquali, 2016). In some cases, the main objective has been to facilitate digital access to castles that are located in remote areas through what we could call "virtual tourism" (Baldi, Pucci, 2016), while other projects have been conceived as a basis for generate the necessary previous documentation for future restoration work (Vrettou, Georgopoulos, 2016). Despite the diversity of objectives, research teams, and methodologies, almost all of these projects share a common denominator: they are limited to case studies, where the digitalization of a single site is carried out. Of all the aforementioned projects, only deviation from this trend is the TOVIVA Project, which has managed to digitalize in $3 \mathrm{D}$ and make online a large number of watchtowers of the sixteenth and seventeenth centuries preserved on the coast of the Valencian region of Spain (Rodríguez-Navarro, 2017). At an international level, there are a few projects that have taken a global approach to the digital documentation of cultural heritage, including castles and fortresses. These projects include the Zamani Project and Cyark, which in the last 15 years have managed to digitize a number of fortified spaces in various countries of the world.

As far as the European arena is concerned, the exponential increase in the number of castles and fortresses digitalization projects is due to the approval of the Digital Agenda for Europe, especially the Commission Recommendation of 27/10/2011 on the digitization and online accessibility of cultural material and digital preservation. At the same time, the European Union has also financed a large number of projects in the field of digital heritage that have undoubtedly contributed to boost 3D digitalization work (Maschner, et al., in press).

\section{Global Digital Heritage (GDH) ${ }^{1}$}

In recent years, together with Cyark and the Zamani Project, a new entity dedicated to 3D digitalization of cultural heritage around the world has emerged. Global Digital Heritage (GDH) is an American non-profit organization created at the end of 2017, but whose members have been working together since 2015. GDH seeks to democratize access to science and knowledge through cultural heritage. To meet this goal, it maintains a policy of open access to the data and the $3 \mathrm{D}$ models it produces. In this way, public and private institutions, museums, researchers and citizens can benefit from the documentation and dissemination work carried out by the entity.

The case selection policy includes all types of monuments, sites and museum pieces, from Prehistory to the twentieth century, regardless of their fame, their inclusion in the World Heritage list, or the media attention they receive. In fact, GDH pays special attention to forgotten or littleknown cultural heritage, which is often at risk and that in many cases lacks adequate documentation. In this line, responds to calls for help made by both public administrations and nonprofit associations or entities are encouraged and appreciated by GDH. The digitalization of fortifications constitutes a priority line of interest and activity within the selection of cases by GDH. To date, just considering Spain, digital documentation has been carried out on 24 fortified sites ranging from the Bronze Age to the Spanish Civil War.

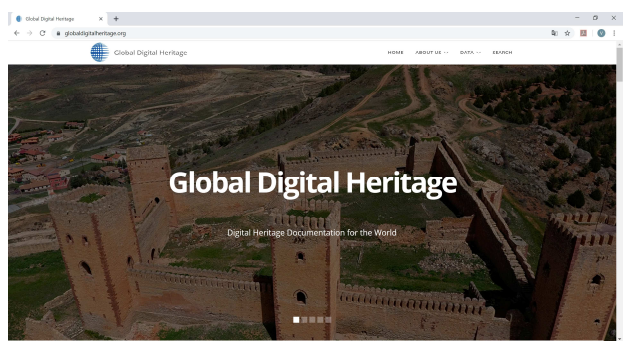

Fig. 1. Website Global Digital Heritage (GDH).

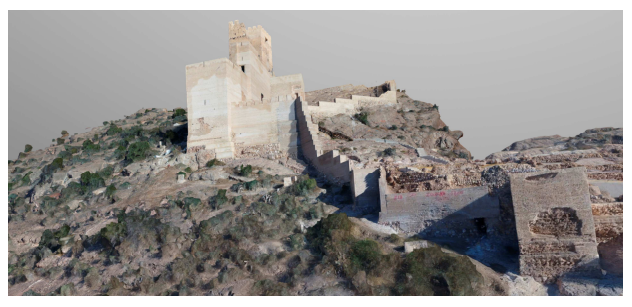

Fig. 2. 3D model of Alhama de Murcia castle digitized by GDH in 2018 . 


\begin{tabular}{|l|l|l|}
\hline \multicolumn{3}{|c|}{ List of fortifications digitized by GDH in Spain } \\
\hline Site & Location & Chronology \\
\hline Calatrava La Vieja Fortress and Town & Carrión de Calatrava & Middle Ages \\
\hline Castle of Alarcos & Ciudad Real & Middle Ages \\
\hline Castle of Miraflores & Piedrabuena & Middle Ages \\
\hline Castle of Montiel & Montiel & Middle Ages \\
\hline Castle of Salvatierra & Calzada de Calatrava & Middle Ages \\
\hline Cerro of las Cabezas Town and Fortress & Valdepeñas & Iron Age \\
\hline Fortified village of Motilla del Azuer & Daimiel & Bronze Age \\
\hline Toledo Gate & Ciudad Real & Middle Ages \\
\hline Casares Tower and Town & Riba de Saelices & Middle Ages \\
\hline Castle of Molina de Aragón & Molina de Aragón & Middle Ages \\
\hline Islamic Tower & Bujarrabal & Middle Ages \\
\hline Castle of Consuegra & Consuegra & Middle Ages, Early modern period \\
\hline Las Paleras Fortress and Town & Alhama de Murcia & Middle Ages \\
\hline Tower of Cope & Aguilas & Early modern period \\
\hline Calatrava La Nueva castle & Aldea del Rey & Middle Ages, Early modern period \\
\hline Castle of Alhama & Alhama de Murcia & Middle Ages \\
\hline Castle of Los Vélez & Mula & Middle Ages, Early modern period \\
\hline Castle of Siyâsa & Cieza & Middle Ages \\
\hline Il Murtal Fortress & Alhama de Murcia & Iron Age \\
\hline Machine Gun Bunker of Alhama & Alhama de Murcia & Spanish Civil War \\
\hline Machine Gun Bunker of Calarreona & Aguilas & Spanish Civil War \\
\hline Machine Gun Bunker, Matalentisco I & Aguilas & Spanish Civil War \\
\hline Machine Gun Bunker, Matalentisco II & Aguilas & Spanish Civil War \\
\hline Civil war airfield & Saceruela & Spanish Civil War \\
\hline & & \\
\hline
\end{tabular}

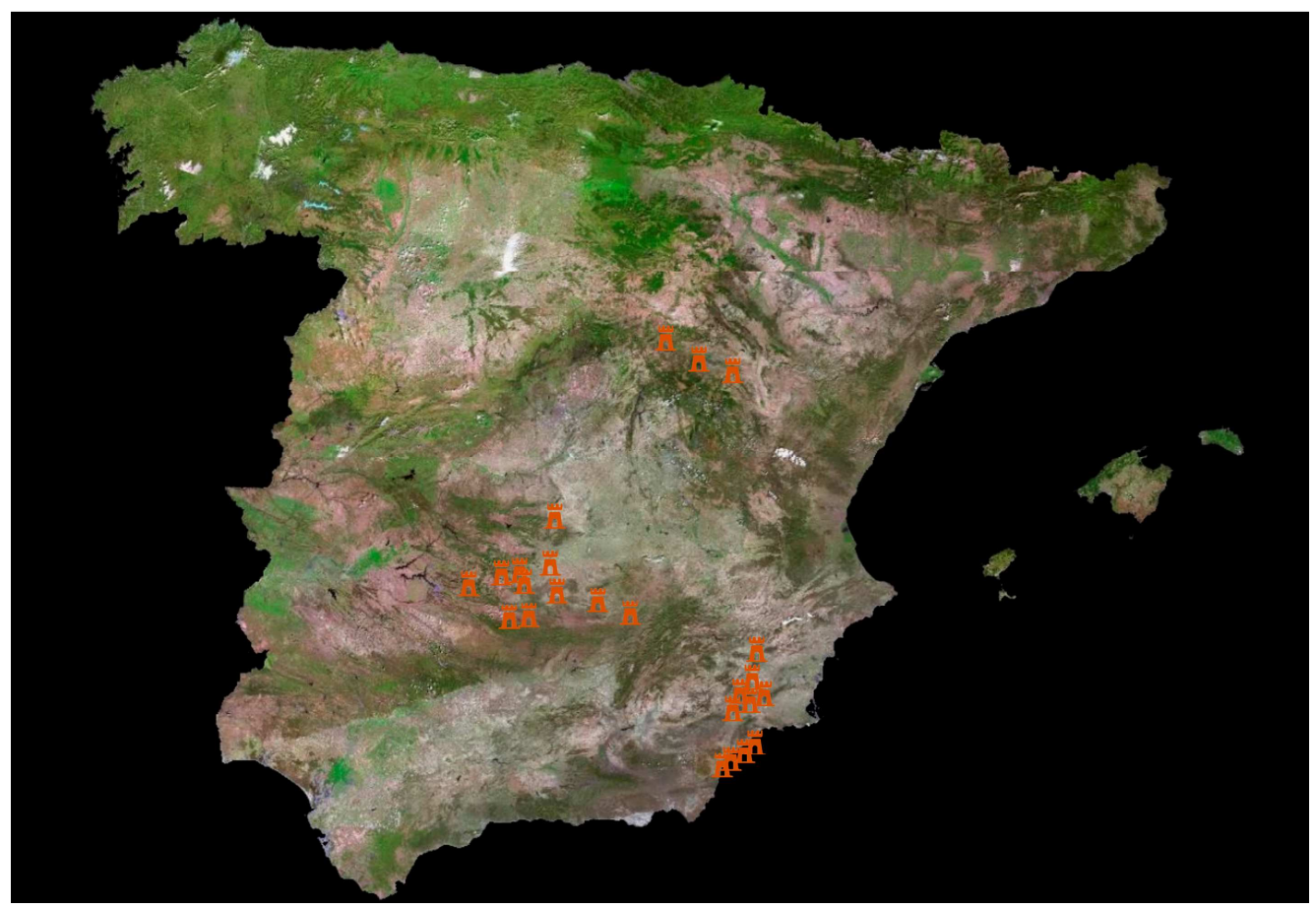

Fig. 3. Location map of the digitized fortifications in Spain. 


\section{Workflow in the digitalization of castles and fortresses in Spain}

For years, the main projects of threedimensional digitization of castles and fortresses have been based on the combined use of professional SLR cameras, drones and 3D laser scanners (Verdiani, 2017; Gonizzi Barsanti, et al., 2017). The combined use of these tools allows projects to generate very precise and complete 3D models that document both the interior and exterior spaces of any fortification.

For its work in fortifications, GDH has two FARO Focus3D S70 laser scanners of considerable precision and speed, two DJI Phantom 4 Pro drones and several Canon EOS 5D Mark IV SLR cameras of 30,4 mpx and Sony $\alpha 7 \mathrm{R}$ III of $42,4 \mathrm{mpx}$. To document the interior of the fortifications, laser scanners have been used as a priority, which allow working in conditions with very low lighting or, even in total darkness, with accuracy levels of $+/-1 \mathrm{~mm}$. However, ground cameras and drones are preferable for digitalization of the exteriors, which offer a total coverage of spaces that are impossible to reach with laser scanners, such as decks or some areas of very difficult access. External laser scan data are often used to create the geometry for the photogrammetry.

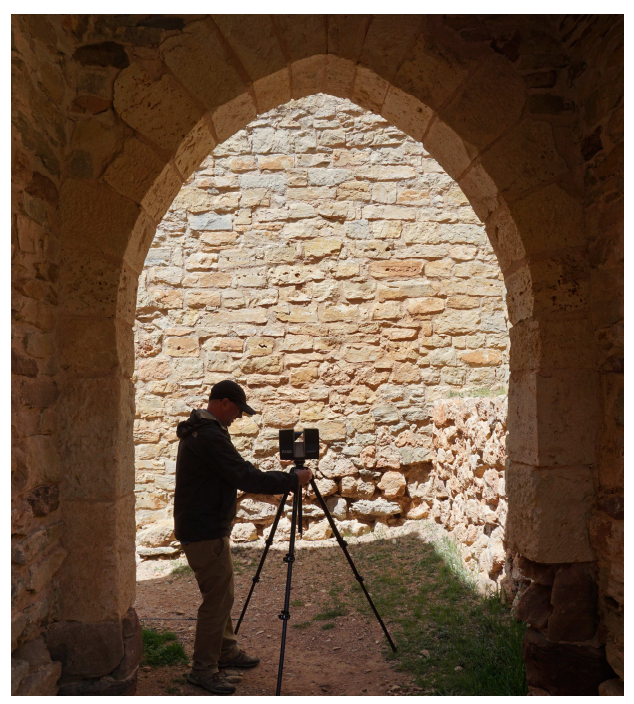

Fig. 4. FARO Focus3D S70 laser scanner working in Molina de Aragón castle.
Although there are many different drones on the market today, we have opted for the use of a DJI Phantom 4 Pro drone and a DJI Phantom 4 Pro + drone, both equipped with a $20 \mathrm{Mpx}$ camera and a very bright $24 \mathrm{~mm}$ lens. The DJI Phantom 4 Pro and Pro + drone has an enormous level of safety thanks to the improvement of obstacle detection systems that incorporate more sensors, which allows it to fly very short distances from the walls without compromising either the device or monument.

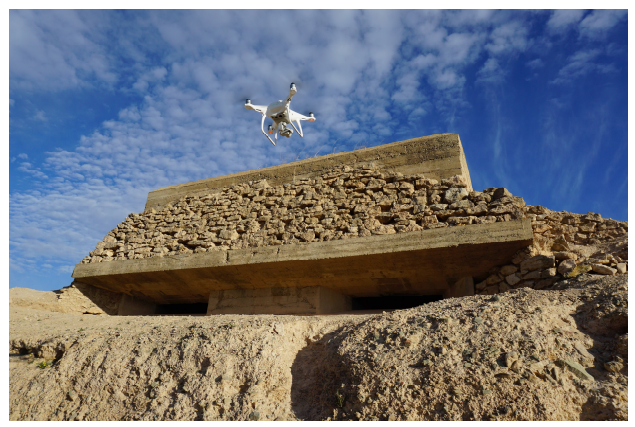

Fig. 5. DJI Phantom 4 Pro drone taking photographs of the machine gun bunker of Alhama de Murcia.

The stability and security of the Phantom 4 Pro has allowed us to make short-range photogrammetry, as close as $5 \mathrm{~m}$, for example in the shields of the castle of Los Vélez in Mula (Murcia, Spain), which dot the walls of the fortress at a height, and in areas, where it is practically impossible to use terrestrial photogrammetry. The case of the castle of Los Vélez serves to perfectly illustrate the work methodology used with drones. On one hand, a scheduled flight of the castle and its surroundings is made, in order to document the landscape where the fortification is located, using the Pix4D free tablet application. That first zenith flight is combined with a second free flight using in this case the DJI Tablet application itself. The objective of the second flight is to obtain photographs at much shorter distances and with the camera in parallel position to each of the visible walls or structures. The smaller the distance between the drone camera and the photographed object, the greater the density of the point cloud obtained. On the other hand, the more frontal the photographs, the lower the distortion and the better the final tex- 
ture. Finally, flights are made to document shields, inscriptions or other details that could be on the walls of the fortifications in areas inaccessible on foot. In this case, between 50 and 80 photographs are taken at the minimum distance allowed by the drone safety sensors. These photographs are processed independently of the general model of the fortress, obtaining specific 3D models of all the details.

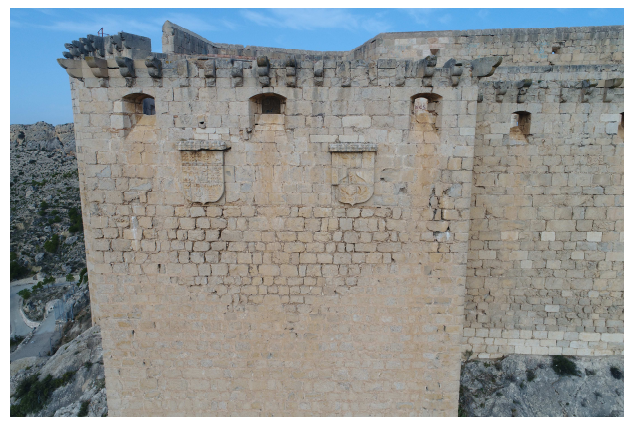

Fig. 6. Aerial view of the castle of Los Vélez (Mula). The walls have numerous shields placed in areas of very difficult access.

Given the limitations of the drone for very low altitude, or areas where there is a lot of vegetation or very high walls close to each other, SLR cameras are used to take photographs from the ground.

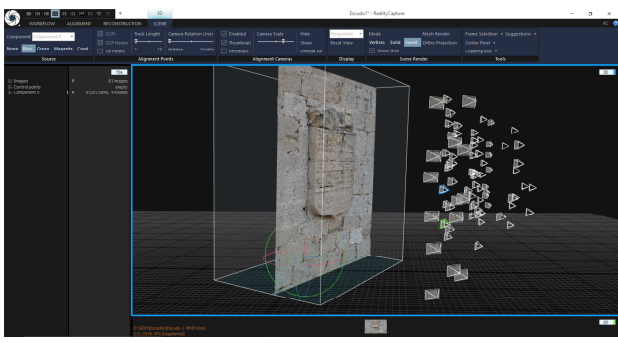

Fig. 7. View of the processing in Reality Capture of one of the shields of the castle of Los Vélez from short range aerial photogrammetry.

All the photographs obtained, both by the drone and by the terrestrial cameras, and all the data collected by the laser scanners, are processed together in Reality Capture software. The incorporation of Reality Capture into the GDH workflow has been a real revolution, since it allows to process an unlimited number of photographs that can also be mixed with the data from the laser scanners.

To increase the visibility and dissemination of these works, GDH has its own account in Sketchfab $^{2}$, in which it has created two specific collections of 3D models of fortifications. The first collection is dedicated to castles in Spain while the second is focused on military structures of the Spanish Civil War (1936-1939).
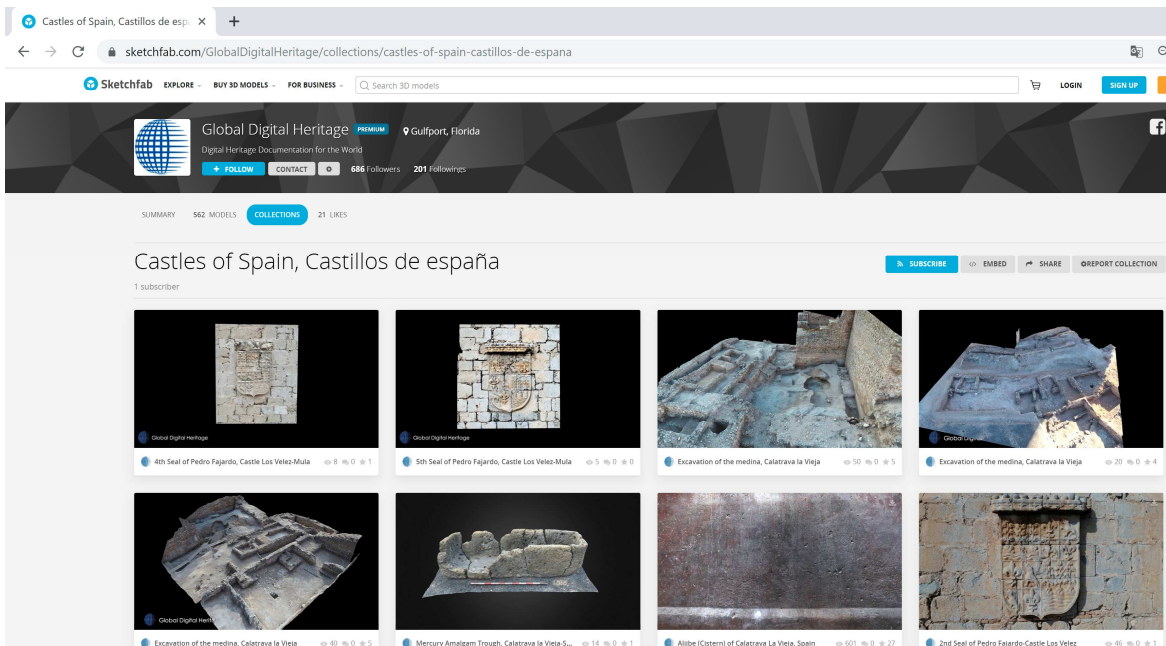

Fig. 8. Collection of "Castles of Spain" by GDH on Sketchfab. 


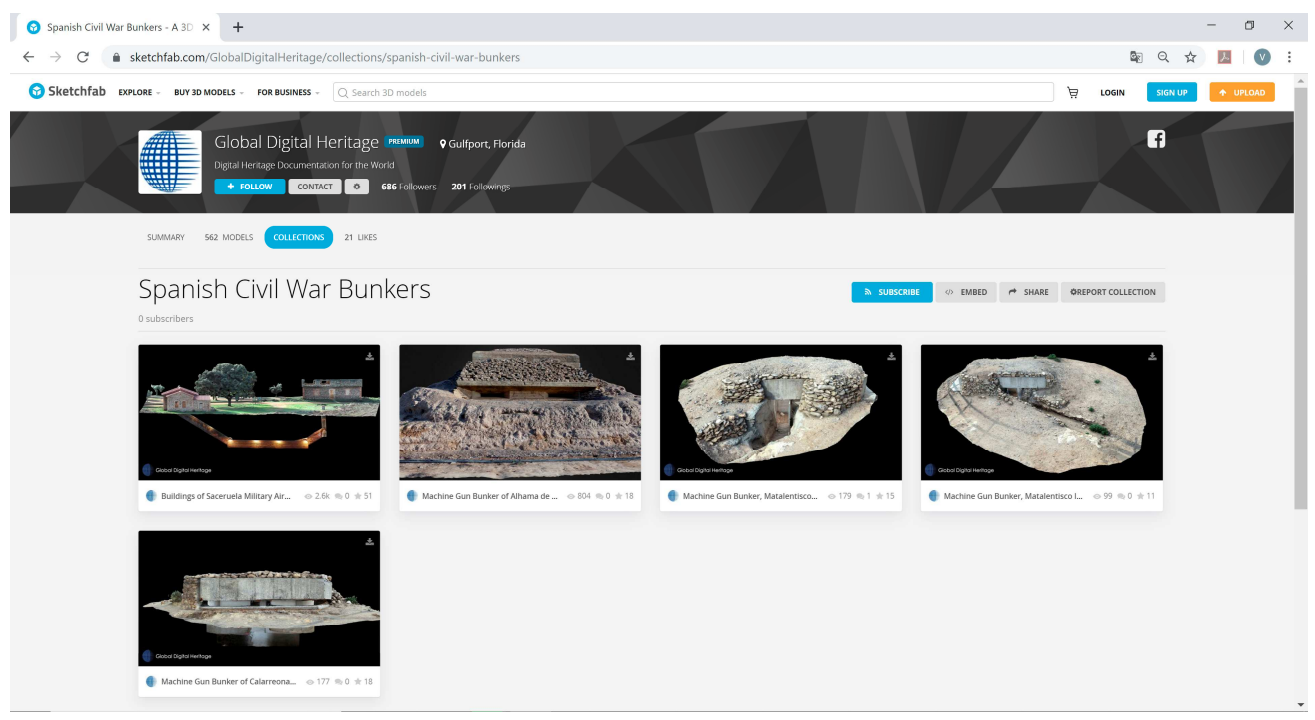

Fig. 9. Collection of "Spanish Civil War Bunkers" by GDH on Sketchfab.

\section{Conclusions}

Despite the huge number of projects developed to date, 3D digitalization of fortifications, in both Spain and the rest of the world, is insufficient. In addition, most of these projects focus on case studies that too often do not get published in open and free format, which in the long term tends to cause an irreparable loss of data.

However, current technology has reached a sufficient point of maturity to work on a large scale in the massive digitization of fortifications, with a level of quality and detail unthinkable only a few years ago. Every year documentation becomes faster and cheaper for these kinds of 3D digitization projects. Direct evidence this are the results that can be obtained with a drone costing less than $3000 €$. The work of GDH in Spain in the digitization of fortifications has shown that drones are versatile work tools, capable of handling the digitization of large areas of land or large monuments but also of specific elements, details or even interiors. The combination of drones and powerful laser scanners allows us to undertake extraordinarily complex work in just a few days of field work.
Digital documentation of this kind of cultural heritage is urgent and necessary, given the risks that threaten its survival in the near term. But the challenge of massively digitizing fortifications around the world will only make sense if in parallel we are able to make all that information available freely to all citizens of the planet. That is the mission of GDH.

\section{Acknowledgment}

Global Digital Heritage acknowledges our sincere gratitude to the General Directorate of Cultural Heritage of the Region of Murcia, to the Vice-Ministry of Culture of the Regional Government of Castilla-La Mancha, and to all the municipalities and technicians who have facilitated the realization of field works.

\section{Notes \\ ${ }^{1}$ https://globaldigitalheritage.org/ \\ ${ }^{2}$ https://sketchfab.com/GlobalDigitalHeritage}




\section{Bibliography}

Almagro, A.; Orihuela, A. (2015). "Métodos para documentar y restaurar zonas de difícil acceso en el Castillo de Salobreña (Granada)", in FORTMED 2015. Defensive architecture of the Mediterranean: XV to XVIII centuries, Rodríguez Navarro, P. ed., vol. 1, pp. 287-290.

Angulo, R. (2013) "La fotogrametría digital: una herramienta para la recuperación de arquitecturas perdidas. Torre del Homenaje del Castillo de Constantina", Virtual Archaeology Review, 4, 8, pp. 140-144.

Baldi, G. ; Pucci, M. (2016). "The Volterraio castle: digital tools for documentation, survey and promotion", in Verdiani, G. Coord., FORTMED 2016. Defensive Architecture of the Mediterranean: XV to XVIII Centuries, pp. 291-300.

Bercigli, M. (2017). "Documentation strategy for coastal towers of the Mediterranean: the case of the tower in the archeological site of Saturo (TA-ITA)", in González Avilés, A.B. coord., FORTMED 2017. Defensive Architecture of the Mediterranean: XV to XVIII Centuries, vol. VI, pp. 337-344.

El-Hakim, S.; Gonzo, L.; Voltolini, F.; Girardi, S.; Rizzi, A.; Remondino, F.; Whiting, E. (2007). "Detailed 3D Modelling of Castles", International Journal of Architectural Computing, 5, 2, pp. 200-220.

Faro, A. Lo; Mangani, M.; Santagati, C. (2016). "La difesa della costa siciliana nel XVI secolo: la torre di Manfria", in Verdiani, G. coord., FORTMED 2016. Defensive Architecture of the Mediterranean: XV to XVIII Centuries, vol. IV, pp. 301-308.

Forte, M. (1997). Virtual archaeology: re-creating ancient worlds, H.N., Abrams.

Gonizzi Barsanti, S.; Guidi, G.; Rodríguez-Navarro, P. (2017). "Geometrical processing of real data for Finite Element Analysis of historical fortified structures", in González Avilés, A.B. coord., FORTMED 2017. Defensive Architecture of the Mediterranean: XV to XVIII Centuries, vol. VI, pp. 377-384.

González-Aguilera, D.; Remondino, F.; Toschi, I.; Rodriguez-Gonzalvez, P.; Stathopoulou, E., eds. (2019). 27th CI$P A$ International Symposium "Documenting the past for a better future", ICOMOS/ISPRS International Scientific Committee on Heritage Documentation (CIPA), vol. IV-2/W6.

Mancuso, A.; Pasquali, A. (2016). "St. Giovanni Tower on the Elba Island: survey and analysis for a digital comprehension", in Verdiani, G. coord., FORTMED 2016. Defensive Architecture of the Mediterranean: XV to XVIII Centuries, vol. IV, pp. 257-264.

Marotta, A.; Marchis, E.T.C.; Netti, R. (2017). "From project drawings to digital modeling in different representation scales. The Citadel of Alessandria", in González Avilés, A.B. coord., FORTMED 2017. Defensive Architecture of the Mediterranean: XV to XVIII Centuries, vol. VI, pp. 319-327.

Maschner, H.D.G.; López-Menchero, V.M.; Duvernay, J.; Hervás, M.Á.; Lureau, A.; Mcleod, J.B. (in press). "La digitalización tridimensional del patrimonio cultural como medida preventiva ante catástrofes y amenazas", in Actas del I Congreso internacional Patrimonio Cultural y catástrofes: Lorca como referencia.

Milella, N.; Zonno, M.; Capotorto, S. (2016). "Il sistema fotogrammetrico 3DEYE per il rilievo 3D in quota: Il Bastione di Sant'Antonio in Bari", in Verdiani, G. coord., FORTMED 2016. Defensive Architecture of the Mediterranean: XV to XVIII Centuries, vol. IV, pp. 323-330.

Muscatelloa, G.; Quartab, A.; Mitelloc, C. (2018). "I sotterranei dei castelli di Otranto e di Gallipoli: dal rilievo laser scanner 3D all'analisi strutturale", in Marotta, Spallone, eds., FORTMED 2018. Defensive Architecture of the Mediterranean, vol IX, Politecnico di Torino, Torino, pp. 1021-1028.

Pignatale, T.; Tramentozzi, I.; Frascari, A. (2016). "Torre di S. Pietro in Bevagna: ir ritorno alla funzione originaria della fortificazione ecclesiastica", in Verdiani, G. coord., FORTMED 2016. Defensive Architecture of the Mediterranean: XV to XVIII Centuries, vol. IV, pp. 283-290.

Rodríguez-Navarro, P.; Verdiani, G.; Gil Piqueras, T. (2015). "Comprehensive Methodology for Documenting the Defense Towers of the valencian Coast (Spain)", in Rodríguez Navarro, P. ed., FORTMED 2015. Defensive architecture of the Mediterranean: XV to XVIII centuries, vol. 1, pp. 321-328.

Rodríguez-Navarro, P.; Verdiani, G.; Gil Piqueras, T. (2016). "TOVIVA project: documenting the spanish defense towers along the Valencian Coast with a comprehensive digital methodology", in Electronic Imaging \& the Visual Arts - EVA 2016 Florence, Firenze University Press, pp. 102-107. 
Rodríguez-Navarro P. (2017). "TOVIVA Project: una experiencia en torno al proyecto de defensa de la costa valenciana entre los siglos XVI al XVII", in González Avilés, A.B. coord., FORTMED 2017. Defensive Architecture of the Mediterranean: XV to XVIII Centuries, vol. VI, pp. 345-352.

Ruiz, J.Á.; Gallego, D.; Peña, C.; Molero, J.M.; Gómez, A. (2015). “Aerial Photogrammetry by drone in archaeological sites with large structures. Methodological approach and practical application in the medieval castles of Campo de Montiel", Virtual Archaeology Review, 6, 13, pp. 5-19.

Verdiani, G. (2017). "Fortifications and documentation: the case of Fortezza Vecchia in Livorno. State of the digital survey 2017", in González Avilés, A.B. coord., FORTMED 2017. Defensive Architecture of the Mediterranean: XV to XVIII Centuries, vol. VI, pp. 311-318.

Verdiani, G.; Salvatori, M.V. (2017). "Before the modern age: the system of the towers in southern Tuscany. Digital tools for a first approach to documentation", in Echarri Iribarren, V. Coord., Defensive Architecture of the Mediterranean: XV to XVIII Centuries, vol. V, pp. 409-416.

Vrettou, F.; Georgopoulos, A. (2016). "Castle Penteskoufi: Geometric Documentation", in Verdiani, G. coord., FORTMED 2016. Defensive Architecture of the Mediterranean: XV to XVIII Centuries, vol. IV, pp. 317-322. 